\title{
TINGKAT KEEFEKTIFAN MEDIA PAPERCRAFT STRUKTUR BUMI DAN MATAHARI TERHADAP HASIL BELAJAR IPA SISWA KELAS V SDN GEDONGOMBO III KECAMATAN SEMANDING KABUPATEN TUBAN
}

\author{
Wendri Wiratsiwi \\ wendriwiratsiwi3489@gmail.com \\ PGSD, FKIP, Universitas PGRI Ronggolawe Tuban
}

\begin{abstract}
Abstrak: Berdasarkan hasil observasi awal di SDN Gedongombo III diperoleh data bahwa dari 27 siswa, yang mencapai ketuntasan belajar pada materi struktur bumi dan matahari ada 17 siswa. Salah satu penyebabnya adalah pemilihan media yang kurang tepat ketika pembelajaran berlangsung. Pemilihan media pembelajaran yang tepat dapat merangsang siswa untuk bersemangat dalam belajar, sehingga hasil belajarnya dapat meningkat. Tujuan penelitian ini adalah untuk mengetahui tingkat efektivitas media papercraft struktur bumi dan matahari terhadap hasil belajar IPA siswa kelas V SDN Gedongombo III Semanding Tuban. Metode penelitian yang digunakan adalah metode eksperimen dengan bentuk penelitian kuasi eksperimen. Desain yang digunakan pada penelitian ini adalah One-Group Pretest-Posttest Design. Penelitian ini dilakukan pada siswa kelas V SDN Gedongombo III yang berjumlah 27 siswa. Instrumen dalam penelitian ini adalah lembar tes hasil belajar siswa kelas V materi struktur bumi dan matahari. Hasil penelitian menunjukkan terdapat perbedaan rata-rata hasil belajar siswa SD sebelum dan sesudah menggunakan media papercraft struktur bumi dan matahari dengan nilai $t=-9,144$ dan $p=0,000$. Ratarata hasil belajar siswa SD setelah menggunakan media papercraft struktur bumi dan matahari lebih tinggi dibandingkan dengan rata-rata hasil belajar siswa sebelum menggunakan media papercraft struktur bumi dan matahari. Penelitian ini juga membuktikan bahwa media papercraft struktur bumi dan matahari memiliki tingkat keefektifan sedang untuk siswa kelas V SDN Gedongombo III Kecamatan Semanding Kabupaten Tuban
\end{abstract}

Kata kunci: Efektivitas, Media Papercraft Struktur Bumi dan Matahari, Hasil Belajar

\section{THE EFFECTIVENESS OF THE EARTH AND SUN STRUCTURAL PAPERCRAFT MEDIA TOWARDS SCIENCE LEARNING OUTCOMES OF FIFTH GRADE STUDENTS OF GEDONGOMBO III ELEMENTARY SCHOOL SEMANDING TUBAN}

\begin{abstract}
Based on the results of preliminary observations at SDN Gedongombo III obtained data that from twenty-seven of students, who achieved mastery learning on the material structure of the earth and the sun there were seventeen of students. One reason is the selection of media that is not appropriate when learning takes place. The selection of the right learning media can stimulate students to be enthusiastic in learning, so that learning outcomes can increase. The purpose of this study was to determine the level of effectiveness of earth and sun structure papercraft media on science learning outcomes of fifth grade students of Gedongombo III Elementary School Semanding Tuban. The research method used was an experimental method with quasi-experimental research. The design used in this study is One-Group PretestPosttest Design. This research was conducted on the fifth grade students of Gedongombo III elementary
\end{abstract}


Wendri, Efektivitas Media Papercraft Struktur...

school, amounting to 27 students. The instrument in this study is a test sheet of student learning outcomes of of fifth grade students material on earth and sun structure. The results showed that there were differences in the average learning outcomes of elementary school students before and after using the paper and earth structure media of the sun with a value of $t=-9.144$ and $p=0,000$. The average learning outcomes of elementary school students after using paper and earth structure media papercraft is higher than the average student learning outcomes before using paper and earth structure media suncraft. This study also proves that the media papercraft of the earth and sun structures have a moderate level of effectiveness for fifth grade students of Gedongombo III Elementary School in Semanding Tuban.

Keywords: Effectiveness, Papercraft, Media Earth and Sun Structures, Learning Outcomes

\section{PENDAHULUAN}

Ilmu Pengetahuan Alam (IPA) merupakan hasil kegiatan manusia berupa pengetahuan, gagasan dan konsep yang terorganisasi tentang alam sekitar yang diperoleh dari pengalaman melalui serangkaian proses ilmiah antara lain: penyelidikan, penyusunan dan pengujian dan mengembangkan pengetahuan, keterampilan, sikap dan nilai ilmiah pada peserta didik serta mencintai dan menghargai Tuhan Yang Maha Esa.

Begitu pentingnya peranan terhadap masa depan bangsa, maka pemerintah telah berusaha untuk meningkatkan mutu pelajaran IPA dengan berbagai upaya misalnya dengan pemberian alat peraga, buku paket, olimpiade IPA serta penyempurnaan kurikulum. Siswa sebagai individu yang potensial tidak dapat berkembang banyak tanpa bantuan guru sebagai pembimbing. Berkaitan dengan peningkatan mutu pendidikan maka perlu adanya perbaikan, pembaharuan, serta perubahan dalam segala aspek diantaranya kurikulum, sarana dan prasarana, guru, siswa serta metode pembelajaran.

Berdasarkan hasil observasi yang dilakukan pada tanggal 27 Februari 2018 di SDN Gedongombo III di kelas V, nilai hasil belajar IPA Pada materi struktur bumi dan matahari belum maksimal, masih banyak nilai siswa yang rendah dan di bawah KKM, yaitu dari 27 orang siswa, yang mencapai ketuntasan ada 17 orang siswa sedangkan yang belum mencapai ketuntasan ada 10 orang siswa dengan persentase ketuntasan klasikal sebesar $62,9 \%$.

Dalam melaksanakan pembelajaran IPA di kelas V SDN Gedongombo III, pada saat penyampaian materi khususnya pada materi struktur bumi dan matahari, peneliti menemukan masih banyak siswa tampak kurang bergairah dan mudah bosan dengan materi yang disampaikan karena guru masih menggunakan media gambar, kurang aktifnya siswa dalam proses pembelajaran seperti saat guru meminta siswa untuk 
Wendri, Efektivitas Media Papercraft Struktur...

mengajukan pertanyaan tidak ada satu pun siswa yang bertanya serta masih banyak siswa tampak tidak dapat menyelesaikan soal dengan baik khususnya pada materi struktur bumi dan matahari Aktivitas kegiatan belajar mengajar yang hanya menggunakan media gambar saja membuat siswa bosan. Penyampaian materi menggunakan media yang tidak sesuai akan membuat siswa jenuh sebagai akibatnya siswa malas belajar dan pengaruh hasil belajar.

Media pembelajaran merupakan salah satu komponen pendukung keberhasilan proses belajar mengajar. Selama kegiatan belajar mengajar, dibutuhkan adanya interaksi antara guru dan siswa, agar siswa dapat menyerap materi pelajaran dengan optimal. Sebagai tenaga pengajar dan pendidik yang secara langsung terlibat dalam proses belajar mengajar, guru memegang peran penting dalam mengarahkan siswa mencapai hasil belajar yang maksimal.

Berdasarkan hasil observasi di lapangan dan latar belakang masalah di atas maka peneliti memilih media Papercraft Struktur Bumi dan Matahari untuk mengatasi permasalahan yang ada, karena papercraft termasuk media model 3D. Media yang berbentuk model 3D lebih mudah untuk dipahami siswa, karena model 3D merupakan pengganti dari benda yang sesungguhnya (Wati, 2016:26).

Pemilihan media pembelajaran yang tepat dapat merangsang siswa untuk bersemangat dalam belajar, sehingga hasil belajarnya dapat meningkat.

Media adalah bagian yang tidak terpisahkan dari proses belajar mengajar demi tercapainya tujuan pembelajaran disekolah. Menurut Arsyad (2014:3) media berasal dari bahasa latin medius yang secara harfiah berarti "tengah", "perantara" atau "pengantar". Pengertian yang dikemukakannya tidak jauh beda dengan pengertian yang dikemukakan oleh Asociation of Education Comunication Technology (AECT) (dalam Arsyad 2014:3), yang mana media diartikan dengan segala bentuk dan saluran yang dapat dipergunakan untuk proses penyalur pesan atau informasi. Sedangkan menurut Wati (2016:3) Media merupakan suatu yang bersifat meyakinkan pesan dan dapat merangsang pikiran, perasaan, dan kemauan audiens atau siswa sehingga dapat mendorong terjadinya proses belajar pada diri siswa tersebut.

Sedangkan papercraft adalah kerajinan yang terbuat dari kertas, seperti asal katanya paper menurut bahasa berarti kertas dan craft berarti kerajian. Seperti namanya media ini menggunakan kertas sebagai bahan utamanya, kertas yang digunakan bisa 
Wendri, Efektivitas Media Papercraft Struktur... menggunakan paper art dan bisa pula menggunakan kertas foto. Kertas sendiri pada dasarnya digunakan untuk media menulis seperti yang dikemukakan oleh Kung (1998:7), pada masa awal-awal keberadaan kertas sangat dekat dengan kegiatan menulis. Menurut Sulianta dan Variant (2010:2) tradisi kerajinan kertas pertama kali muncul di India. Kerajinan kertas berkembang semenjak ditemukannya proses pembuatan kertas pada tahun 1200-an. Kertas merupakan media yang menarik untuk dieksperimentasikan, mulai dari berkreasi dengan kertas berukuran kecil hingga kertas berukuran besar, baik dengan bentuk 2D (lembaran) maupun bentuk 3D.

Papercraft yang akan digunakan sebagai media pembelajaran ini merupakan papercraft 3D atau paper model yang berbentuk miniatur model struktur bumi dan matahari, seperti yang dikemukakan oleh Sulianta dan Ongkowijoyo (2015:10) papercraft adalah karya seni kertas untuk menghasilkan obyek tiga dimensi dengan cara membuat model, mewarnai, menggunting, serta merekatkan, dan ini berbeda dengan Origami yang menggunakan trik lipat melipat.

Berdasarkan beberapa pendapat di atas dapat disimpulkan bahwa media papercraft adalah suatu media pembelajaran visual yang berbentuk 3D yang terbuat dari kertas dengan model tertentu, sehingga akan membuat siswa lebih tertarik dengan materi yang akan dibahas karena menggunakan kertas yang dibuat dengan model atau replika dari bentuk aslinya.

Langkah- langkah penggunaan media Papercraft Struktur Bumi dan Matahari adalah sebagai berikut:
a. Persiapan
b. Pembentukan kelompok
c. Tiap kelompok harus memiliki buku paket
d. Diskusi masalah
e. Pemanggilan nomor angota dan penjelasan menggunakan media papercraft struktur bumi dan matahari
f. Memberi kesimpulan

Berdasarkan latar belakang yang telah dijabarkan di atas, maka rumusan masalah dalam penelitian ini adalah; (1) Apakah ada perbedaan hasil belajar siswa kelas V SDN Gedongombo III sebelum dan sesudah menggunakan media Papercraft Struktur Bumi dan Matahari?; (2) Bagaimana tingkat keefektifan dari media Papercraft Struktur Bumi dan 
Wendri, Efektivitas Media Papercraft Struktur...

Matahari untuk siswa kelas V SDN Gedongombo III Kecamatan Semanding Kabupaten Tuban?. Berdasarkan rumusan masalah yang ada, maka tujuan yang dicapai dalam penelitian ini adalah; (1) untuk mengetahui ada tidaknya perbedaan hasil belajar siswa kelas V SDN Gedongombo III sebelum dan sesudah menggunakan media Papercraft Struktur Bumi dan Matahari; (2) mendeskripsikan tingkat keefektifan dari media Papercraft Struktur Bumi dan Matahari untuk siswa kelas V SDN Gedongombo III Kecamatan Semanding Kabupaten Tuban".

\section{METODE}

Metode penelitian yang digunakan adalah metode eksperimen dengan bentuk penelitian kuasi eksperimen. Desain yang digunakan pada penelitian ini adalah OneGroup Pretest-Posttest Design. Pada desain ini, kelas diberikan perlakuan dengan memberikan pretest dan posttest. Pada desain ini, diawal penelitian dilakukan pengukuran terhadap variabel terikat yang telah dimiliki subjek. Setelah diberikan perlakuan, dilakukan pengukuran kembali terhadap variabel terikat dengan alat ukur yang sama Adapun bentuk desainnya sebagai berikut:

$$
\mathrm{O}_{1} \quad \mathrm{X} \quad \mathrm{O}_{2}
$$

Keterangan:

$\mathrm{X}=$ Treatment/perlakuan yakni pembelajaran IPA dengan menggunakan media papercraft.

O1 = Pengukuran pemahaman konsep peserta didik sebelum pembelajaran dengan media papercraft.

$\mathrm{O} 2$ = Pengukuran pemahaman konsep peserta didik setelah pembelajaran media papercraft.

Lokasi penelitian dilaksanakan di SDN Gedongombo III kecamatan Semanding kabupaten Tuban tahun pelajaran 2017/2018. Waktu penelitian dilaksanakan pada semester II tahun pelajaran 2017/2018 mulai bulan Maret 2018 sampai dengan bulan April 2018. 


\section{Wendri, Efektivitas Media Papercraft Struktur...}

Subyek penelitian adalah siswa kelas V semester genap SDN Gedongombo III kecamatan Semanding kabupaten Tuban yang berjumlah 27 siswa, terdiri dari 12 siswa laki-laki dan 15 siswa perempuan.

Instrumen dalam penelitian ini adalah soal-soal dalam bentuk pilihan ganda (multiple choice) yang terdiri dari 10 soal dengan tingkatan kompetensi kognitif $\mathrm{C} 1$ (pengetahuan) sebanyak 8 soal dan C2 (pemahaman) sebanyak 2 soal.

Teknik pengumpulan data yang digunakan dalam penelitian ini adalah tes hasil belajar. Setelah didapat data hasil pretest-posttes kemudian dihitung gainnya untuk mengetahui peningkatan hasil belajar siswa sebelum dan sesudah menggunakan media papercraft. Untuk lebih jelasnya dapat dilihat dari rumus di bawah ini:

$\mathrm{N}$ - Gain $(\mathrm{G})=\frac{\text { skor posttest }- \text { skor pretest }}{\text { skor maksimal-skor pretest }}$

(Meltzer dalam Husein, dkk, 2015:222)

Hasil perhitungan tersebut kemudian dibandingkan dengan kriteria $\mathrm{N}$-gain yang dapat dilihat pada tabel 1 berikut ini.

Tabel 1. Kategori Tingkat N-gain

\begin{tabular}{|c|c|}
\hline Rentang & Kategori \\
\hline $\mathrm{g}>0,7$ & Tinggi \\
\hline $0,3 \leq \mathrm{g} \leq 0,7$ & Sedang \\
\hline $\mathrm{g}<0,3$ & Rendah \\
\hline
\end{tabular}

(Meltzer dalam Husein, dkk, 2015:222)

Tahap berikutnya adalah pengolahan data pretest dan posttest dengan menggunakan program software Statistical Package For Sosial Sciences (SPSS) 20 for windows. Analisis data yang digunakan yaitu Paired Sample T-Test . Tujuan pengujian dengan Paired Sample T - Test adalah untuk membandingkan nilai hasil belajar siswa kelas V SDN gedongombo III sebelum dan setelah diberikan media pembelajaran sebelum dan sesudah menggunakan media Papercraft Struktur Bumi dan Matahari.

\section{HASIL}

Peneliti melakukan pretest dan posttest kepada subjek penelitian untuk melihat perbedaan hasil belajar IPA materi struktur bumi dan matahari pada siswa kelas V SDN Gedongombo III Kecamatan Semanding Kabupaten Tuban sebelum dan setelah diberikan 
Wendri, Efektivitas Media Papercraft Struktur...

media pembelajaran berupa papercraft tentang struktur bumi dan matahari. Hasil dari nilai pretest dan posttest dapat dilihat pada Tabel 2 berikut:

Tabel 2. Data pretest dan posttest siswa kelas V

\begin{tabular}{|c|c|c|c|c|c|}
\hline No & Subjek & Pretest & Posttest & Gain (G) & Kategori \\
\hline 1 & A A K R & 70 & 80 & 10 & Sedang \\
\hline 2 & A P & 70 & 80 & 10 & Sedang \\
\hline 3 & I S & 60 & 80 & 20 & Sedang \\
\hline 4 & A B N F & 60 & 90 & 30 & Tinggi \\
\hline 5 & D R A & 50 & 80 & 30 & Sedang \\
\hline 6 & D S & 60 & 90 & 30 & Tinggi \\
\hline 7 & E A R & 60 & 80 & 20 & Sedang \\
\hline 8 & E S T T B & 50 & 60 & 10 & Rendah \\
\hline 9 & I D K P & 70 & 90 & 20 & Sedang \\
\hline 10 & J F D L & 60 & 80 & 20 & Sedang \\
\hline 11 & L F & 50 & 80 & 30 & Sedang \\
\hline 12 & M W S K & 80 & 90 & 10 & Rendah \\
\hline 13 & M A Y & 70 & 80 & 10 & Sedang \\
\hline 14 & M E & 60 & 70 & 10 & Rendah \\
\hline 15 & $\mathrm{O} \mathrm{N} \mathrm{W}$ & 60 & 80 & 20 & Sedang \\
\hline 16 & R B P & 70 & 80 & 10 & Sedang \\
\hline 17 & R S J & 80 & 90 & 10 & Rendah \\
\hline 18 & $\mathrm{Ra}$ & 70 & 80 & 10 & Sedang \\
\hline 19 & $\mathrm{Ri}$ & 50 & 80 & 30 & Sedang \\
\hline 20 & R N P & 80 & 80 & 0 & Rendah \\
\hline 21 & S K & 70 & 80 & 10 & Sedang \\
\hline 22 & S Y P & 70 & 80 & 10 & Sedang \\
\hline 23 & $\mathrm{VT}$ & 80 & 80 & 0 & Rendah \\
\hline 24 & S R B & 70 & 90 & 20 & Sedang \\
\hline 25 & A H W & 70 & 90 & 20 & Sedang \\
\hline 26 & $\mathrm{LS}$ & 70 & 80 & 10 & Sedang \\
\hline 27 & $\mathrm{NH}$ & 60 & 90 & 30 & Tinggi \\
\hline Jumlah & $\mathrm{N}=27$ & 1770 & 2210 & 440 & \\
\hline \multicolumn{2}{|c|}{ Rata-rata } & 65,6 & 81,9 & & \\
\hline
\end{tabular}

Sedangkan untuk mengetahui ada tidaknya perbedaan hasil belajar siswa kelas $\mathrm{V}$ SDN Gedongombo III sebelum dan sesudah menggunakan media Papercraft Struktur Bumi dan Matahari peneliti menggunakan Uji Paired Sample T-Test. Adapun hasil uji Uji Paired Sample T-Test dapat dilihat pada Tabel 3 berikut:

Tabel 3. Perhitungan Uji Paired Sample T- Test

\begin{tabular}{|c|c|c|c|c|c|}
\hline \multirow{2}{*}{ Kelompok } & \multirow{2}{*}{ N } & \multicolumn{2}{|c|}{ Rerata Nilai } & T & \multirow{2}{*}{ Sig. } \\
\cline { 3 - 4 } & & Pretest & Posttest & & \\
\hline Eksperimen & 27 & 65,56 & 81,85 & $-9,144$ &, 000 \\
\hline
\end{tabular}

\section{PEMBAHASAN}

Berdasarkan analisis uji Paired Sample $\mathrm{T}$ - Test pada Tabel 3 di atas menunjukkan nilai t sebesar -9,144 dan uji signifikan menunjukkan hasil (p) $0,000<0,05$ 
Wendri, Efektivitas Media Papercraft Struktur...

dengan tingkat signifikansi adalah 5\%. Hal ini menunjukkan bahwa ada perbedaan ratarata hasil belajar IPA materi struktur bumi dan matahari pada siswa kelas V SDN Gedongombo III Kecamatan Semanding Kabupaten Tuban sebelum dan setelah diberikan media papercraft struktur bumi dan matahari. Nilai rata-rata posttest yaitu 81,85 lebih tinggi dibandingkan dengan nilai rata-rata pretest yaitu 65,56.

Pemilihan media pembelajaran yang tepat dapat merangsang siswa untuk bersemangat dalam belajar, sehingga hasil belajarnya dapat meningkat. Peneliti memilih media Papercraft Struktur Bumi dan Matahari untuk mengatasi permasalahan yang ada, karena papercraft termasuk media model 3D. Media yang berbentuk model 3D lebih mudah untuk dipahami siswa, karena model 3D merupakan pengganti dari benda yang sesungguhnya.

Berdasarkan hasil perhitungan rata-rata hasil belajar menunjukkan adanya peningkatan hasil belajar siswa sebelum dan sesudah menggunakan media papercraft yaitu 65,56 sebelum menggunakan media papercraft dan 81,85 sesudah menggunakan media papercraft.

Berdasarkan nilai perolehan gain ternormalisasi pada Tabel $\mathbf{2}$ di atas menunjukkan bahwa gain ternormalisasi terendah adalah 0,2 yang dikategorikan rendah dan nilai gain ternormalisasi tertinggi 0,75 yang dikategorikan tinggi. Kemudian nilai rata-rata gain ternormalisasi yaitu 0,47 termasuk dalam kategori sedang, siswa yang masuk dalam kategori gain ternormalisasi tinggi berjumlah 3 siswa dan kategori gain ternormalisasi sedang berjumlah 18 siswa, sedangkan kategori rendah berjumlah 6 siswa. Hal ini menunjukkan bahwa media papercraft struktur bumi dan matahari efektif digunakan untuk meningkatkan hasil belajar siswa kelas V SDN Gedongombo III pada materi struktur bumi dan matahari, dengan kategori sedang.

\section{SIMPULAN}

Berdasarkan hasil penelitian dapat disimpulkan bahwa terdapat perbedaan ratarata hasil belajar siswa SD sebelum dan sesudah menggunakan media papercraft struktur bumi dan matahari dengan nilai $\mathrm{t}=-9,144$ dan $\mathrm{p}=0,000$. Rata-rata hasil belajar siswa SD setelah menggunakan media papercraft struktur bumi dan matahari lebih tinggi dibandingkan dengan rata-rata hasil belajar siswa sebelum menggunakan media papercraft struktur bumi dan matahari. Penelitian ini juga membuktikan bahwa media 
Wendri, Efektivitas Media Papercraft Struktur...

papercraft struktur bumi dan matahari memiliki tingkat keefektifan sedang untuk siswa kelas V SDN Gedongombo III Kecamatan Semanding Kabupaten Tuban.

\section{DAFTAR RUJUKAN}

Arsyad, Azhar. 2014. Media Pembelajaran. Jakarta: Rajawali Pers.

Husein, Umar. 2015. Metode Penelitian untuk Skripsi dan Tesis. Jakarta: Rajawali

Kung, Hans. 1998. The Complete book Of Papercraft. London: Hermes House.

Sulianta, Feri \& Ongkowijoyo, Samuel. 2015. Yuk Rakit \& Jualan Paper Craft Sendiri. Jakarta: PT Elex Media Komputindo.

Sulianta, Feri \& Variant, Johan. 2010. Papercraft - Dari Design Kreatif Hingga Bisnis. Jakarta: PT Elex Media Komputindo.

Wati, Ega Rima. 2016. Ragam Media Pembelajaran. Yogyakarta: Kata Pena. 